Original Article

\title{
Tingkat Kecemasan dengan Lama Rawat Inap Covid 19
}

\author{
Retno Wulandari ${ }^{1}$, Aisyah Safitri ${ }^{2}$, Sri Mintasih ${ }^{3}$ \\ ${ }_{1,2,3}$ Program Studi Ilmu Keperawatan \\ ${ }^{1,2,3}$ Sekolah Tinggi Ilmu Kesehatan Indonesia Maju \\ Jl.Harapan nomor 50, Lenteng Agung-Jakarta Selatan 12610 \\ Email: retnoabi9@gmail.com ${ }^{1}$
}

\begin{abstract}
Introduction: The patient's level of anxiety while undergoing treatment at the hospital greatly affects the length of stay in the hospital.

Purpose: The purpose of this study was to determine the relationship between the anxiety level of COVID-19 patients and the length of patient care in the COVID-19 inpatient room at the Kalideres Hospital, Jakarta in 2021. Methods: This type of quantitative research is correlative with a cross-sectional approach. The population in this study were covid 19 patients in the inpatient room for covid 19 patients at Kalideres Hospital, Jakarta in 2021 and the sample needed in this study was 54 respondents with the accidental sampling method. The researcher's data analysis used the Spearman-Ro Rank test.

Results: Based on the results of the study, the description of the level of anxiety of most of the patients' anxiety was severe anxiety, as many as 26 respondents $(48.1 \%)$. The description of the length of treatment partly is long, as many as 38 respondents $(70.4 \%)$. The results of statistical tests are known with the value of $\mathrm{P}=0.000<0.05$.

Conclusion: There is a relationship between the anxiety level of COVID-19 patients and the length of patient care in the inpatient room at the Kalideres Hospital in 2021.
\end{abstract}

Keywords: anxiety, covid 19, length of treatment

Editor: Yt

Hak Cipta:

(C2021 Artikel ini memiliki akses terbuka dan dapat didistribusikan berdasarkan ketentuan Lisensi Atribusi Creative Commons, yang memungkinkan penggunaan, distribusi, dan reproduksi yang tidak dibatasi dalam media apa pun, asalkan nama penulis dan sumber asli disertakan. Karya ini dilisensikan di bawah Lisensi Creative Commons Attribution Share Alike 4.0 Internasional. 


\section{Pendahuluan}

Covid-19 adalah penyakit menular yang disebabkan oleh tipe baru Coronavirus dengan gejala umum demam, kelemahan, batuk, kejang dan diare. ${ }^{1}$ Pada desember 2019, sejumlah pasien dengan pneumonia misterius dilaporkan untuk pertama kalinya di Wuhan, Cina. ${ }^{2}$ Virus ini telah dinamai sindrom pernafasan (SARS-CoV-2) dan dapat bergerak cepat dari manusia satu ke manusia lain melalui kontak langsung. ${ }^{1}$ Kejadian kasus Covid-19 terus bertambah dari hari kehari sehingga banyaknya pasien dengan diagnosa Covid-19 yang dirawat di Rumah Sakit, selain dengan isolasi mandiri sebagian besar pasien harus masuk rumah sakit karena adanya keluhan-keluhan tambahan, terlebih lagi pasien memiliki komorbid atau penyakit penyerta sebelumnya. ${ }^{3}$ Tanda dan gejala penyakit covid 19 adalah secara umum demam, batuk kering, dan kelelahan, gejala yang sedikit tidak umum rasa tidak nyaman dan nyeri, diare, sakit kepala, hilangnya indera perasa atau penciuman, hingga gejala serius seperti kesulitan bernafas atau sesak nafas, nyeri dada atau rasa tertekan pada dada, hilangnya kemampuan berbicara atau bergerak. ${ }^{4}$ Gejala ringan sampai berat ini yang dapat mengakibatkan kecemasan pada pasien karena gejala yang bisa mengakibatkan henti nafas sewaktu-waktu. ${ }^{4}$

Menurut organisasi kesehatan dunia (WHO) pada 6 April 2020, jumlah pasien penderita di dunia adalah 1.278.523 yang terinfeksi kasus Covid-19. Dari 1,2 juta kasus positif corona, 69.757 (5,46\%) pasien Covid telah meninggal dan 266.732 (20,9\%) orang telah dinyatakan sembuh dari total kasus positif. ${ }^{5}$ Sedangkan di Indonesia, data terakhir tentang jumlah kasus positif virus korona (Covid-19) masih diperoleh peningkatan 2.491 kasus. Tingkat kematian pasien Covid-19 juga terus meningkat 209 orang $(8,39 \%)$ dan 192 orang $(7,70 \%)$ dinyatakan sembuh dari jumlah penderita positif. ${ }^{6}$ Dari perbandingan data tersebut bahwa di Indonesia masih mengalami peningkatan dari jumlah kematian dan tingkat kesembuhan pasien. ${ }^{7}$

Rumah Sakit adalah pusat pelayanan kesehatan, tempat dimana orang sakit maupun orang sehat jadi satu, atau sebagai tempat penularan penyakit serta kemungkinan bisa terjadi pencemaran lingkungan dan gangguan kesehatan. ${ }^{8}$ Rumah sakit terdapat beberapa jenis pelayanan diantaranya pelayanan medik, pelayanan penunjang medik, pelayanan perawatan, pelayanan rehabilitasi, pencegahan dan peningkatan kesehatan, sebagai sarana pendidikan dan atau pelatihan medik dan non medik. ${ }^{8}$ Rawat inap adalah perawatan yang mengharuskan pasien untuk menginap di rumah sakit dengan jangka waktu tertentu, bisa dalam waktu singkat dan bisa lama tergantung dengan diagnosanya. Lama rawat inap adalah lama hari rawat atau Leght Of Stay (LOS) adalah suatu ukuran berapa hari lamanya seorang pasien dirawat pada suatu periode perawatan. ${ }^{9}$

Dapat dilihat pada Keputusan Mentri Kesehatan Republik Indonesia HK.01.07/MENKES/4641/2021 tentang panduan pelaksanaan pemeriksaaan, pelacakan, karantina dan isolasi dalam rangka percepatan pencegahan dan pengendalian Covid 19 yaitu isolasi dilakukan sejak seseorang suspek mendapatkan perawatan di Rumah Sakit atau seseorang dinyatakan terkonfirmasi Covid-19, paling lama dalam 24 jam sejak kasus terkonfirmasi. Kriteria selesai isolasi dan sembuh pada kasus terkonfirmasi Covid-19 menggunakan gejala sebagai patokan utama, yaitu Pada kasus terkonfirmasi yang tidak bergejala (asimtomatik), isolasi dilakukan selama sekurang-kurangnya 10 hari sejak pengambilan spesimen diagnosis konfirmasi. ${ }^{10}$ Pada kasus terkonfirmasi yang bergejala, isolasi dilakukan selama 10 hari sejak muncul gejala ditambah dengan sekurang-kurangnya 3 hari bebas gejala demam dan gangguan pernapasan. Sehingga, untuk kasus-kasus yang mengalami gejala selama 10 hari atau kurang harus menjalani isolasi selama 13 hari. ${ }^{10}$ 
Kriteria pasien konfirmasi yang dinyatakan selesai isolasi antara lain, yang pertama kasus konfirmasi tanpa gejala (asimptomatik) adalah pasien konfirmasi asimptomatik tidak dilakukan pemeriksaan follow up RT-PCR. Dinyatakan selesai isolasi apabila sudah menjalani isolasi mandiri selama 10 hari sejak pengambilan spesimen diagnosis konfirmasi. Kriteria kedua adalah Kasus konfirmasi dengan gejala ringan dan gejala sedang. ${ }^{10}$ Pasien konfirmasi dengan gejala ringan dan gejala sedang bisa diputuskan selesai isolasi oleh DPJP dengan dasar Pasien sudah 10 hari dari tanggal onset dengan minimal 3 hari sudah tidak lagi menunjukkan gejala demam dan gangguan pernapasan, PCR telah negatif $2 \mathrm{kali}$ atau positif dengan batas $C T$ Value yg telah ditetapkan oleh RS sesuai dengan jenis alat yang digunakan.kriteria ketiga adalah kasus konfirmasi dengan gejala berat/kritis yang dirawat di rumah sakit, Pasien konfirmasi dengan gejala berat/kritis dinyatakan bisa diputuskan selesai isolasi oleh DPJP dengan dasar Pasien sudah 10 hari dari tanggal onset dengan dengan minimal 3 hari sudah tidak lagi menunjukkan gejala demam dan gangguan pernapasan, PCR telah negatif 2 kali atau positif dengan batas $C T$ Value ditetapkan RS sesuai dengan jenis alat yang digunakan. ${ }^{10}$

Kriteria pasien dinyatakan sembuh Pasien konfirmasi tanpa gejala, gejala ringan, gejala sedang, dan gejala berat/kritis dinyatakan sembuh apabila telah memenuhi kriteria selesai isolasi dan dikeluarkan surat pernyataan selesai pemantauan. Pasien konfirmasi dengan gejala berat/kritis dimungkinkan memiliki hasil pemeriksaan follow up RT-PCR persisten positif, karena pemeriksaan RT-PCR masih dapat mendeteksi bagian tubuh virus Covid-19 walaupun virus sudah tidak aktif lagi (tidak menularkan lagi). Terhadap pasien tersebut, maka penentuan sembuh berdasarkan hasil assessmen yang dilakukan oleh DPJP. ${ }^{11}$

Kecemasan dapat menjadi peringatan untuk individu supaya dapat mempersiapkan diri pada ancaman atau bahaya yang akan terjadi. Bila seseorang tersebut bisa menyikapi dengan baik, maka kecemasan tersebut kecemasan yang tidak wajar sehingga bisa memperburuk kondisinya. Kecemasan berkelanjutan bisa menyebabkan efek fisik yang berpotensi merusak tubuh. ${ }^{12}$

Riskesdas mendata masalah gangguan kesehatan mental emosional (depresi dan kecemasan) sebanyak 9,8\%. Hal ini terlihat peningkatan jika dibandingkan data Riskesdas tahun 2013 sebanyak 6\%. Tingginya peningkatan masalah kesehatan mental emosional berdasarkan kelompok umur, persentase tertinggi pada usia 65-75 tahun keatas sebanyak 28,6\%, disusul kelompok umur 55- 64 tahun sebanyak 11\%, kemudian kelompok umur 45-54 tahun dan 15-24 tahun memiliki persentase yang sama sebanyak $10 \% .{ }^{13}$ Beragam penyebab kecemasan yang muncul terkait dengan pandemic Covid-19. Hal ini memicu timbulkan gangguan fisik dan psikis bila tidak segera ditangani atau dikontrol. Kecemasan pada pasien dengan dugaan Covid-19 yang dikonfirmasi membutuhkan observasi medis yang ketat dan isolasi selama perawatan. Dalam kasus ini, ilmuan banyak melakukan study tentang kecemasan pasien Covid-19 menemukan, dalam bingkai pembatasan sosial pasien terhadap kontak sosialnya, tidak hanya beratnya menanggung rasa sakit fisik yang parah, depresi umum dialami pasien sebab kecemasan eksternal. Kecemasan adalah hal yang normal bagi semua manusia, akan tetapi menjadi tidak normal bila berlebihan dan mengakibatkan gangguan fisik, psikis, dan social. ${ }^{14}$

RSUD Kalideres terdapat 5 ruangan khusus covid, diantaranya ruang HCU Covid ruangan ini terdiri dari 5 bed terdiri dari pasien yang dalam kesadaran coma, apatis, bahkan ada yang sudah pemulihan, ruang Isolasi Covid 19 terdiri dari 2 bed ini ruangan khusus untuk pasien diagnosa Covid dengan gejala seperti mempunyai komorbid atau penyakit bawaan, ruang rawat inap Covid terdiri dari 16 bed, ini ruang rawat inap khusus pasien Covid tanpa 
gejala atau kondisi Covid dalam kondisi yang stabil, serta ruang bersalin Covid khususnya untuk ibu hamil yang terkena Covid 19, di lengkapi juga dengan ruangan Perina khusus dengan bayi yang lahir dari ibu suspect atau terkonfirmasi Covid 19.

Berdasarkan studi pendahuluan data yang diperoleh di RSUD Kalideres dari bulan september sampai dengan februari tahun 2021 adalah 486 pasien, namun ada perubahan jumlah pasien di tanggal 22 juli - 25 agustus sebanyak 116 pasien, karena angka Covid yang naik turun. Dari 6 Ruangan termasuk ruang HCU Covid tersebut telah dilakukan wawancara pada 10 orang pasien, berdasarkan pengukuran skala DAAS didapatkan kecemasan ringan terdapat 2 orang pasien dengan lama rawat 8 hari, kecemasan sedang terdapat 3 pasien dengan lama rawat 15 hari, dan kecemasan berat terdapat 5 orang pasien dengan lama rawat 20 hari lebih. Kondisi pasien dengan kecemasan berat sering memperlambat kesembuhan pasien sehingga lama rawat bertambah. Dengan kondisi seperti inilah imunitas mereka jadi berkurang, karena kecemasan termasuk rasa ketakutan yang berlebihan. Semakin mereka tampak cemas dan takut semakin menurun imunitasnya, sehingga dapat memperpanjang masa perawatan. Beda dengan pasien berskala kecemasan ringan dan sedang, kondisi mereka masih bisa terkontrol dan tidak begitu mempengaruhi imunitas pasien, sehingga kesembuhan lebih cepat dan masa perawatan pun hanya sebentar.

Dari latar belakang diatas menarik peneliti untuk melakukan penelitian dengan judul "Hubungan tingkat kecemasan dengan lamanya perawatan pasien Covid 19 di ruang rawat inap Covid RSUD Kalideres Jakarta 2021”.

\section{Metode}

Jenis penelitian dalam penelitian ini adalah kuantitatif teknik penelitian cross sectional. Populasi dalam penelitian ini adalah pasien Covid 19 RSUD Kalideres tahun 2021 dari 22 Juli26 Agustus sebanyak 116 pasien. Sampel penelitian ini sebanyak 54 responden. Teknik pengambilan sampel menggunakan metode accidental sampling. Instrumen yang digunakan dalam penelitian ini adalah menggunakan lembaran kuesioner dan observasi. Kuesioner yang berterkaitan kecemasan pasien dan lembar observasional lama rawat. Penelitian ini menggunakan analisa chi square. Peneitian ini telah lulus uji etik di Komisi Etik Penelitian Kesehatan dengan surat keterangan, nomor: 1722/Sket/Ka-Dept/RE/STIKIM/II/2021.

\section{Hasil}

Tabel 1. Gambaran Usia, Jenis Kelamin, Pendidikan, dan pekerjaan Responden ( $\mathrm{N}=54)$

\begin{tabular}{|c|c|c|}
\hline Variabel & Frekuensi & Persentase (\%) \\
\hline \multicolumn{3}{|l|}{ Usia } \\
\hline$\leq 40$ tahun & 20 & 37,0 \\
\hline$\neq \geq 40$ tahun & 34 & 63,0 \\
\hline \multicolumn{3}{|l|}{ Pekerjaan } \\
\hline IRT & 8 & 14,8 \\
\hline PNS/POLRI & 13 & 24,1 \\
\hline Swasta & 33 & 61,1 \\
\hline \multicolumn{3}{|l|}{ Pendidikan } \\
\hline SMP & 2 & 3,7 \\
\hline SMA & 33 & 61,1 \\
\hline Perguruan tinggi & 19 & 35,2 \\
\hline \multicolumn{3}{|l|}{ Jenis kelamin } \\
\hline Laki-laki & 22 & 40,7 \\
\hline Perempuan & 32 & 59,3 \\
\hline
\end{tabular}


Berdasarkan tabel 1 menunjukkan distribusi data demografi responden di ruang rawat inap covid 19 RSUD Kalideres didapatkan paling banyak usia $\neq \geq 40$ tahun sebanyak 34 responden $(63,0 \%)$, pekerjaan didapatkan pegawai swasta sebanyak 33 responden $(61,1 \%)$, pendidikan dengan lulusan SMA sebanyak 33 responden $(61,1 \%)$, dan jenis kelamin lebih dominan perempuan sebanyak 32 responden $(59,3 \%)$.

Tabel 2. Gambaran Tingkat Kecemasan dan lama rawat inap $(\mathrm{N}=54)$

\begin{tabular}{lll}
\hline Variabel & Frekuensi & $\%$ \\
\hline Tingkat kecemasan & & \\
Cemas ringan & 5 & 9,3 \\
Cemas sedang & 19 & 35,2 \\
Cemas berat & 26 & 48,1 \\
Cemas berat sekali & 4 & 7,4 \\
\hline Lama rawat & & 29,6 \\
\hline Cepat & 16 & 70,4 \\
Lama & 38 & \\
\hline
\end{tabular}

Berdasarkan tabel 2 menunjukan bahwa sebagian besar data yang diperoleh adalah responden yang memiliki tingkat kecemasan cemas berat sebanyak 26 responden $(48,1 \%)$. Dan di lama perawatan didapatkan lama perawatan lama sebanyak 38 responden $(70,4 \%)$.

Tabel 3. Hubungan Tingkat Kecemasan dengan lamanya perawatan pasien covid ranap RSUD Kalideres $(\mathrm{N}=54)$

\begin{tabular}{lccc}
\hline Variabel & $\mathbf{n}$ & $\begin{array}{c}\text { Correlation } \\
\text { Coefficient }\end{array}$ & Sig. (2-tailed) \\
\hline Tingkat kecemasan & $\mathbf{5 4}$ & $.736^{* *}$ & .000 \\
\hline Lama perawatan & $\mathbf{5 4}$ & $.736^{* *}$ & .000
\end{tabular}

Berdasarkan tabel 3 menunjukkan dari 54 responden, tingkat kecemasan dan lama perawatan diperoleh nilai correlation coeffition 0,736 yang artinya jika nilai correlation coeffetion 0,6 - <0,8 interpretasi kekuatan korelasi adalah kuat. Adapun nilai signifikansi 0,000 artinya jika sig $<0,05$ maka terdapat korelasi atau hubungan antara dua variabel yang di uji, karena nilai correlation coeffition 0,736 maka arah hubungan penelitian ini adalah positif atau searah. Sehingga interpretasinya semakin berat tingkat kecemasan maka semakin lama proses perawatannya.

\section{Pembahasan}

\section{Analisis Univariat}

\section{Data Demografi}

Penelitian ini mendapatkan hasil mengenai data karakteristik responden berupa usia, status pendidikan, dan status pekerjaan, dan jenis kelamin. Usia responden yang di dapatkan paling banyak usia usia $\geq 40$ tahun sebanyak 34 responden $(63,0 \%)$, dan $\leq 40$ tahun sebanyak 20 responden $(37,0 \%)$. Hasil penelitian ini menunjukkan bahwa tingkat kecemasan pasien dengan lama rawat inap dipengaruhi oleh dua faktor diantaranya internal dan eksternal. Pengaruh faktor eksternal yaitu usia, jenis kelamin, perubahan lingkungan dan perubahan sosial yang ditangkap oleh pasien covid $19 .{ }^{14}$ 
Penelitian ini sesuai dengan penelitian Rupu, 2015 yang menyatakan bahwa orang tua yang berada pada usia dewasa muda dan akhir sudah mengalami kematangan fisik dan psikologis sehingga dapat mengontrol dengan baik emosi yang terjadi dan dengan menghadapi masalah-masalah tersebut dalam melatih kedewasaannya yang akan membuat orang tua dapat menempatkan diri dan berusaha mencari penyelesaian masalahnya. Pada dewasa muda seorang individu menyesuaikan dengan kondisi yang ada, belajar menempatkan diri dan memahami kondisi yang terjadi.

Hasil penelitian ini juga sejalan dengan penelitian yang dilakukan karima, 2017 dengan judul "hubungan tingkat kecemasan dengan hari rawat pada pasien akut miokard infark". Mayoritas responden terdiri dari umur 50-65 tahun sebanyak 19 responden (63,3\%), kemudian umur 40-50 tahun sebanyak 9 responden (30.0\%), dan yang paling rendah umur $>66$ tahun sebanyak 2 responden $(6,7 \%) .{ }^{15}$

Variabel lain yang diteliti dan diperkirakan terdapat hubungan dengan faktor yang mempengaruhi tingkat kecemasan dengan lama perawatan adalah pekerjaan, pendidikan, dan jenis kelamin namun pada variabel Pendidikan dan pekerjaan tidak ada hubungan yang signifikan antara tingkat kecemasan dengan lama rawat inap. ${ }^{15}$ Sedangkan pada jenis kelamin dengan tingkat kecemasan ada hubungan signifikan, Menurut dengan kecemasan pada pria dan wanita, perempuan lebih cemas akan ketidakmampuanya dibanding dengan lakilaki, laki-laki lebih aktif ekploratif, sedangkan perempuan lebih sensitive. Gangguan kecemasan berbeda dengan perasaan cemas yang normal, gejala yang sering terjadi untuk alasan yang tidak terbukti dan tidak hilang begitu saja. Pada kebanyakan kasus wanita lebih banyak menderita kecemasan dibanding dengan pria, diperkirakan jumlah wanita yang menderita gangguan kecemasan baik akut maupun kronik mencapai 5\% dari jumlah penduduk, dengan perbandingan antara wanita dan pria 2 banding 1. Pada umumnya seorang laki-laki dewasa mempunyai mental yang kuat terhadap sesuatu hal yang dianggap mengancam bagi dirinya dibandingkan perempuan. ${ }^{16}$

Hasil distribusi jenis kelamin Sri Purnama (2012) Faktor-Faktor yang berhubungan dengan tingkat kecemasan pada pasien Fraktur yang Akan menjalani Pemasangan Traksidi RSUP.DR. Wahidin Sudirohusodo Makassar yang menunjukan lebih dari separoh $(67,1 \%)$ berjenis kelamin laki-laki. Fraktur cenderung terjadi pada laki-laki dan sering berhubungan dengan olah raga, pekerjaan, dan banyaknya melakukan aktifitas di luar rumah. ${ }^{17}$

Menurut asumsi peneliti, bahwa jenis kelamin mempengaruhi kecemasan dikarenakan wanita dan laki-laki mempunyai karakter yang berbeda. Pada wanita lebih sangat banyak yang difikirkan dan dikerjakan, terkait dengan kondisi rumah, kondisi anak sehari-hari, misal urusan sekolah anak-anak, dan juga kegiatan dilingkungan rumah, hal ini yang mebuat tingkat kecemasan semakin tinggi, berbeda dengan laki-laki yang mungkin hanya yang dipikirkan pekerjaan dan kegiatan lingkungan yang jarang diikuti.

Adapun faktor eksternal seperti uraian diatas, ada juga faktor internal yang mempengaruhi lama rawat inap diantaranya seperti komorbid, imunitas, batuk, hypertermi, sesak nafas dan ketidaknyamanan fisik yang lain. Seperti dalam penelitian yang dilakukan oleh kangdra, 2013 dengan judul karakteristik klinis dan faktor komorbid pada Pasien dalam Pengawasan (PDP) Covid-19 yang dirawat di RS Mitra Medika Amplas, didapatkan karakteristik klinis yang paling banyak dijumpai pada PDP Covid-19 adalah batuk, yang dijumpai pada 91 orang $(82,7 \%)$, diikuti oleh gejala demam pada 71 orang $(64,5 \%)$, sesak napas pada 66 orang $(60 \%)$, mual dan muntah pada 64 orang $(58,2 \%)$, nyeri perut pada 23 
orang $(20,9 \%)$, nyeri menelan dan pilek/hidung tersumbat pada 16 orang $(14,5 \%)$, dan diare pada 12 orang $(10,9 \%)$. Komorbiditas merupakan gejala klinis tambahan yang mempengaruhi imunitas pasien, sehingga lama rawat pada pasien tersebut sangat dipengaruhi. ${ }^{3}$

Menurut asumsi peneliti, komorbiditas dan gejala tambahan seperti batuk, demam, diare sangat mempengaruhi lama perawatan di rumah sakit. Seperti halnya kondisi pasien di RSUD Kalideres tidak sedikit yang mengalami kritis bahkan sampai meninggal akibat keparahan gejala tambahan dan komorbiditas penyakit penyerta.

\section{Tingkat kecemasan pasien covid 19}

Hasil penelitian ini menunjukkan bahwa yang memiliki tingkat kecemasan ringan sebanyak 5 responden $(11,9 \%)$, cemas berat sebanyak sedang sebanyak 14 responden $(33,3 \%)$, cemas berat sebanyak 19 responden $(45,2 \%)$, cemas berat sekali 4 responden $(9,5 \%)$.

Ada beberapa tingkatan kecemasan yang dialami oleh responden penelitian ini mulai dari kecemasan ringan sampai dengan kecemasan berat sekali. Akan tetapi sebagian besar responden mengalami tingkat kecemasan berat sebanyak 19 responden (45,2\%). Kecemasan merupakan respon individu terhadap suatu keadaan yang tidak menyenangkan, yakni menggambarkan keadaan kehawatiran, kegelisahan yang tidak menentu, dan terkadang disertai dengan keluhan fisik. Tiap manusia memiliki rasa cemas apabila menghadapi suatu kejadian atau peristiwa. Kecemasan adalah hal yang normal bagi semua manusia, akan tetapi menjadi tidak normal bila berlebihan dan mengakibatkan gangguan fisik, psikis, dan social. ${ }^{17}$

Kecemasan pada pasien dengan dugaan Covid-19 yang dikonfirmasi membutuhkan observasi medis yang ketat dan isolasi selama perawatan. Dalam kasus ini, ilmuan banyak melakukan study tentang kecemasan pasien Covid-19 menemukan, dalam bingkai pembatasan sosial pasien terhadap kontak sosialnya, tidak hanya beratnya menanggung rasa sakit fisik yang parah, depresi umum dialami pasien sebab kecemasan eksternal. Seperti sedang memikirkan kondisi keluarga dirumah, kabar korban yang telah berjatuhan juga berimbas pada daya dukung psikologis pasien menurun. Kecemasan pada pasien dengan dugaan Covid-19 yang dikonfirmasi membutuhkan observasi medis yang ketat dan isolasi selama perawatan. Dalam kasus ini, ilmuan banyak melakukan study tentang kecemasan pasien Covid-19 menemukan, dalam bingkai pembatasan sosial pasien terhadap kontak sosialnya, tidak hanya beratnya menanggung rasa sakit fisik yang parah, depresi umum dialami pasien sebab kecemasan eksternal. $^{14}$

\section{Lama rawat inap pasien covid 19}

Pada hasil distribusi frekuensi lama rawat inap menunjukkan bahwa responden yang mengalami lama perawatan rata-rata perawatan lama sebanyak 27 responden $(64,3 \%)$, perawatan cepat sebanyak 32 responden $(39,0 \%)$. Yang paling dominan adalah perawatan lama. ${ }^{18}$ Bila seseorang dirawat di rumah sakit, maka yang diharapkan baik oleh tenaga medis maupun oleh penderita itu sudah tercapai maka tentunya tidak ada seorangpun yang ingin berlama-lama di rumah sakit. Variasi lama rawat ini dipengaruhi oleh beberapa faktor antara lain keparahan penyakit, mutu pelayanan rumah sakit dan mekanisme koping, di dalam mekanisme koping keluarga sangat berperan, menurut Syamsiah, 2012 menyatakan bahwa dukungan emosional keluarga sebagai tempat yang aman dan damai untuk istirahat dan pemulihan serta membantu penguasaan terhadap emosi. ${ }^{9}$

Penelitiannya Rosi \& Yertizal (2012) tidak jauh berbeda, yang dilakukan di RSUP DR.M. Djamil Padang menyebutkan bahwa lama hari rawat inap penderita SKA berkisar 6-9 
hari. Lama rawat pasien dengan gangguan fungsi jantung di RSU Tugurejo berkisar antara 1 hingga 5 hari. Hal ini didukung oleh data rata-rata lama hari rawat pasien yang dirawat di ruang ICVCU RSUD Dr. Moewardi 3-5 hari. Menurut Heryati, lama hari rawat merupakan salah satu unsur atau aspek asuhan pelayanan rumah sakit yang dapat dinilai atau diukur. ${ }^{19}$

Menurut data hasil yang didapat lebih dominan ke lama perawatan, penyakit Covid 19 merupakan penyakit baru yang oleh WHO dinyatakan sebagai pandemik, kesiapan pasien atau penderita saat dirawat karena terjangkit penyakit tersebut membuat banyak pasien yang cemas, akibatnya banyak pasien yang seharusnya sembuh jadi lama kesembuhannya. Diakibatkan oleh tingkat kecemasan yang berlebihan, sehingga sistem imun semakin menurun dan membuat perawatan di rumah sakit semakin lama.

\section{Analisis Bivariat}

Subjek penelitian ini merupakan pasien Covid 19 di ruang rawat inap RSUD Kalideres. Responden yang ada di ruang rawat inap Covid 19 sering cemas terlihat dari cara pasien yang selalu tampak kebingungan dan menangis. Hasil penelitian menunjukkan bahwa sebagian besar responden mengalami tingkat kecemasan berat dan lama perawatan lama.

Kecemasan bisa dirasakan bila individu mempunyai kepekaan lingkungan, pasien yang baru pertama dirawat di rumah sakit dihadapkan pada situasi dan lingkungan baru sehingga kemampuan adaptasi pasien akan mempengaruhi kecemasan. Menurut Utama, kecemasan timbul akibat ketidakmampuan berhubungan interpersonal dan sebagai akibat dari penolakan. ${ }^{20}$

Penelitian Sagala, (2020) mengemukakan bahwa kecemasan yang tidak tertangani sepenuhnya akan menyebabkan serangan ulang pada pasien akut miokard infark, sehingga dapat menyebabkan kecemasan yang timbul akan lebih besar dari yang sebelumnya. Hasil menunjukkan bahwa dari 30 responden yang didapatkan, mayoritas menjalani lama rawat sedang sebanyak 17 responden dengan presentase $(56,7 \%), 13$ responden $(43,3 \%)$ menjalani lama rawat dan tidak ada responden yang menjalani hari rawat lama. ${ }^{19}$

Berdasarkan tabel 3 uji korelasi menggunakan Spearman menunjukkan hasil korelasi Spearman antara kecemasan dengan lama hari rawat dimana nilai signifikansi tingkat kecemasan dan lama perawatan diperoleh nilai correlation coeffition 0,730 yang artinya jika nilai correlation coeffetion $0,6-<0,8$ interpretasi kekuatan korelasi adalah kuat. Adapun nilai signifikansi (p) 0,000 artinya jika sig < 0,05 maka terdapat korelasi atau hubungan antara dua variabel yang di uji, karena nilai correlation coeffition 0,730 maka arah hubungan penelitian ini adalah positif atau searah. Sehingga interpretasinya semakin berat tingkat kecemasan maka semakin lama proses perawatannya.

Hasil penelitian ini sejalan dengan penelitian karima, (2017) dengan judul hubungan antara kecemasan dan lama tinggal pada pasien infark miokard di Rumah Sakit Umum ICVCU Dr. Moewardi, didapatkan uji korelasi menggunakan Spearman menunjukkan hasil korelasi Spearman antara kecemasan dengan lama hari rawat dimana nilai signifikansi (p) 0.041 karena nilai $\mathrm{p}<0.05$ maka Ho ditolak artinya ada hubungan antara tingkat kecemasan dengan lama hari rawat, sehingga terdapat hubungan yang signifikan antara tingkat kecemasan dengan lama hari rawat. ${ }^{15}$

Menurut asumsi peneliti, hubungan tingkat kecemasan dengan lama rawat inap pasien Covid 19 di RSUD Kalideres terlihat banyak terjadi pada pasien rawat inap Covid akhir-akhir ini. Dan ini perlu dijadikan perhatian khusus oleh perawat dan dookter di rumah sakit. Kecemasan pasien bisa terjadi dari berbagai faktor seperti faktor usia dan faktor komorbiditas 
penyakit, kecemasan seperti ini membuat imunitas pasien menurun, akibatnya membuat pasien lama menjalankan perawatan di rumah sakit.

\section{Kesimpulan}

Berdasarkan penelitian yang telah dilakukan mengenai Hubungan tingkat kecemasan pasien Covid 19 dengan lamanya perawatan pasien di ruang rawat inap Covid 19 RSUD Kalideres Jakarta maka dapat disimpulkan sebagai berikut. Ada Hubungan tingkat kecemasan pasien Covid 19 dengan lama rawat pasien di ruang rawat inap covid 19 RSUD Kalideres Jakarta. Diharapkan sering memberikan konseling kepada pasien Covid 19 yang sedang dalam pemulihan di rumah sakit.

\section{Konflik Kepentingan}

Peneliti menyatakan bahwa penelitian ini independen dari konflik kepentingan individu dan organisasi.

\section{Ucapan Terima Kasih}

Terimakasih kepada seluruh pihak yang telah berkontribusi membantu proses penelitian ini.

\section{Pendanaan}

Sumber pendanaan diperoleh dari peneliti.

\section{Daftar Pustaka}

1. Belakang AL. No Title. 2020;1-9.

2. Otálora MMC. Yuliana. Parq los afectos Jóvenes que cuentan. 2020;2(February):124-37.

3. Kangdra WY. Karakteristik Klinis Dan Faktor Komorbid Pada Pasien Dalam Pengawasan (Pdp) Coronavirus Disease 2019 (Covid-19) Di Rs Mitra Medika Amplas. Vol. 2019. 2021.

4. Stuart GW, Keliat BA, Pasaribu J. Keperawatan Kesehatan Jiwa Stuart. Singapore: Elsevier. 2016;1-31.

5. Susilo A, Rumende CM, Pitoyo CW, Santoso WD, Yulianti M, Herikurniawan H, et al. Coronavirus Disease 2019: Tinjauan Literatur Terkini. J Penyakit Dalam Indones. 2020;7(1):45.

6. Barani Sanassouh. Parsi flor dan prakanesh geografi gyahan der link dengan provinsi dar, taman di wilayah Iranshahr-Istan. 148(2):148-62.

7. Ahmad AS, Baharuddin R. Faktor yang Mempengaruhi Kecemasan pada Tenaga Kesehatan Dalam Upaya Pencegahan Covid-19. 2020;(April):57-65.

8. Akmaliyah M. Gambaran Pengelolaan Linen Rumah Sakit Umum Pusat Sanglah Denpasar Tahun 2018. J Chem Inf Model. 2013;53(9):1689-99.

9. Ekawati A, Afridah W. Hubungan Antara Lama Hari Rawat Dengan Antrian Masuk Rumah Sakit Pada Pasien Bpjs Di Rs. Islam Jemursari Surabaya. J Heal Sci. 2018;8(1):97-103.

10. Keputusan Menteri Kesehatan Republik Indonesia. Keputusan Menteri Kesehatan Republik Indonesia Nomor HK.01.07/MenKes/413/2020 Tentang Pedoman Pencegahan dan Pengendalian Corona Virus Disease 2019 (Covid-19). MenKes/413/2020. 2020;2019:207.

11. Nursofwa RF, Sukur MH, Kurniadi BK, . H. Penanganan Pelayanan Kesehatan Di Masa Pandemi Covid19 Dalam Perspektif Hukum Kesehatan. Inicio Legis. 2020;1(1):1-17.

12. Tobergte DR, Curtis S. Kecemasan. J Chem Inf Model [Internet]. 2013;53(9):1689-99. Available from: http://eprints.uny.ac.id/9709/2/BAB 2 -07104244004.pdf

13. Khoiriyah R, Handayani S. Kesehatan Mental Emosional Perempuan Penderita Kanker di Indonesia. Jkmm. 2020;3(2):164-73.

14. Jannah RJ, Jatimi A, Azizah MJ, Munir Z, Rahman HF. Kecemasan Pasien COVID-19: A Systematic Review. J Penelit Kesehat Suara Forikes [Internet]. 2020;11(2):33-7. Available from: https://scholar.google.com/scholar?hl=id\&as_sdt=0\%2C5\&q=kecemasan+pasien+covid+yang+dirawat + di+rumah+sakit\&btnG=

15. Karima A, Setyorini Y. Hubungan Tingkat Kecemasan Dengan Lama Hari Rawat Pada Pasien Akut Miokard Infark (AMI) DI Ruang ICVCU RSUD DR. Moewardi Surakarta. J Keperawatan Glob. 2017;2(1):21-8. 
16. Hidayanti N. Hubungan Perilaku Caring Perawat dengan Tingkat Kecemasan Pasien Rawat Inap di Rumah Sakit PKU Muhammadiyah Surakarta. Naskah Pubikasi Univ Muhammadiyah Surakarta. 2013;10.

17. Saleh U. Anxiety Disorder (Memahami gangguan kecemasan: jenis-jenis, gejala, perspektif teoritis dan Penanganan). Kesehatan. 2019;1-58.

18. Utami R, Puji Rahayu P. Hubungan Lama Hari Rawat Dengan Tanda Dan Gejala Serta Kemampuan Pasien Dalam Mengontrol Halusinasi. J Keperawatan Jiwa. 2018;6(6):106-15.

19. Sagala SH, Maifita Y, Armaita. Jurnal Menara Medika https://jurnal.umsb.ac.id/index.php/menaramedika/index JMM 2020 p-ISSN 2622-657X, e-ISSN 27236862. J Menara Med. 2020;2(2):119-27.

20. Kusumadewi S, Wahyuningsih H. Model Sistem Pendukung Keputusan Kelompok untuk Penilaian Gangguan Depresii, Kecemasan dan Stress Berdasarkan DASS-42. J Teknol Inf dan Ilmu Komput. 2020;7(2):219. 